\title{
Chain of Custody certification among Malaysian wooden furniture manufacturers: status and challenges
}

\begin{abstract}
Malaysia, a major producer and exporter of wood products has been slow to embrace wood products certifi cation. A study was carried out with the intention of assessing the status of chain of custody certifi cation among wooden furniture manufacturers. A structured questionnaire was used to interview fi rms who participated at the annual Malaysian International Furniture Fair in 2007. Results indicate that the readiness to adopt chain of custody certifi cation among wooden furniture manufacturers was low. The lack of price premiums, limited market potential and high cost were cited as the primary reasons deterring furniture manufacturers from adopting chain of custody certifi cation. Furthermore, the use of plantation wood resources, such as Rubberwood (Hevea brasiliensis Müll. Arg.), were perceived by many respondents to be certifi ed wood resources, refl ecting a lack of understanding among manufacturers. It was concluded that the promotion of chain of custody certifi cation in Malaysia must focus on increasing awareness as well as highlighting the tangible and intangible benefi ts to be gained from such a scheme.
\end{abstract}

Keyword: Chain of Custody $(\mathrm{CoC})$ certifi cation, rubberwood, wood products, price premium, market potential 